\title{
Analysis of Vertical Traffic Calming Measures in Impacts on Road Safety and Environment in Lithuania State Roads
}

\author{
Laura Čygaitė, Ineta Lingytè, Mantvydas Strumskys \\ Road Research Institute, Vilnius Gediminas Technical University, Linkmenu str. 28, LT-08217 Vilnius, Lithuania
}

\begin{abstract}
Several years after implementation of vertical traffic calming measures on roads, crossing cities and settlements, for the first time in Lithuania the research was carried out to determine their effect on the change in the number of accidents, their severity and noise within the operation zone of speed humps, raised pedestrian crossings and speed bumps. The paper present research methodology and analysis of results of vertical traffic calming influence to the road safety and environment in Lithuania roads. It presents that engineering measures have a positive impact on the improvement of the road index to safety. The study of vertical traffic calming measures impact to environment showed that it does not increase equivalent noise level of vehicle in its installation places.
\end{abstract}

Keywords: Equivalent noise level; injury traffic accident; vertical traffic calming measures.

\section{Introduction}

In order to maintain or reduce a permissible speed limit, to improve pedestrian and bicycle traffic conditions and a social climate of local inhabitants in the cities, towns and settlements of Lithuania that are crossed by the roads of national significance, since 2007 more than 250 of vertical traffic calming measures have been installed on the roads of the country. After a certain time period from the installation of engineering safety measures it is important to assess their impact on road safety and environment. It is necessary to determine if road safety measures installed in particular locations give a positive impact.

A level of road safety in the country is decribed by the number of fatal and injury acidents, the number of people killed or injured. In 2012, the damage to Lithuanian economy due to 1 person killed on road amounted to LTL 1,9 million, due to 1 person injured - LTL 172,5 thousand [1]. Statistics of road accidents on Lithuanian roads shows that the largest amount of accidents is representd by collisions with pedestrians (in $2012-35 \%$ ) and collisions (in $2012-30 \%$ ).

Noise has the largest negative impact on hearing. Noise also negatively affects human activities and even the whole human organism [2]. Vehicle-generated noise depends on driving speed. Road pavement type affect tyres/road noise that comes out of vehicles when tyres interact with the surface [3], [4]. Noise dispersion depends on local relief and obstacles situated within the road of sound propagation [5].

In foreign countries the effects of vertical traffic calming measures on the change in the number of road accidents, severity and noise have been studied for already many years. 12 streets in Salt Lake City, Utah were assessed by Cottrell, Kim, Martin and Perrin in order to evaluate the impact of speed humps (width 4,3 m) and speed table (width 6,7 m) to road safety [6]. According to Kokowski and Makarewicz [7] the change in noise level due to a road bump ( $\Delta \mathrm{L})$ was calculated using measurements of sound exposure level. The reduction of road traffic noise by a speed bump has been determined to be $\Delta \mathrm{L} \approx 0,4 \mathrm{~dB}$. The changes in the level of noise emission from a car when passing over two different dimensions speed bumps have been experimentally and numerically investigated by Behzad, Hodaei and Alimohammadi [8].

However, research of the effect of engineering traffic calming measures on road safety and environment is still topical. The effects of vertical traffic calming measures have been evaluated in a number of studies. Based on that studies Elvik, Høye, Vaa and Sørensen presents that implementing speed humps on roads reduces the number of injury accidents about $41 \%$ [9]. In New York City where the speed bumps and other 12 safety countermeasures installed reductions in various

Corresponding author: Laura Čygaitė. E-mail address: laura.cygaite@vgtu.lt

http://dx.doi.org/10.3846/enviro.2014.150

(C) 2014 The Authors. Published by VGTU Press. This is an open-access article distributed under the terms of the Creative Commons Attribution License, which permits unrestricted use, distribution, and reproduction in any medium, provided the original author and source are credited. 
types of accidents were evaluated by Chen, Ewing, McKnight, Srinivasan and Roe [10]. Daniel, Nicholson and Koorey investigated the impacts of the $75 \mathrm{~mm}$ speed hump and $100 \mathrm{~mm}$ speed hump on light vehicle speed and noise emission [11].

Several years after implementation of vertical traffic calming measures on roads, crossing cities and settlements, for the first time in Lithuania the research was carried out to determine their effect on the change in the number of accidents, their severity and noise within the operation zone of speed humps, raised pedestrian crossings and speed bumps. Noise level measurements at vertical traffic calming measures were conducted by Environmental Protection Institute of Environmental Engineering Faculty of Vilnius Gediminas Technical University (VGTU). The aim of research was to determine if after implementation of vertical traffic calming measures the accident rate within the action zone of measures has reduced and if due to implementation of measures the traffic-generated noise has not increased.

\section{Selection of vertical traffic calming measures}

On sections of the roads of national significance, for the research purposes 53 places were selected by the type of speed humps and 10 additional sections by the settlement. The list of speed humps selected for the research (53 pieces) by their type consists on:

- speed humps of trapeze shape (8 pieces);

- raised pedestrian crossings (20 pieces);

- speed bumps (10 pieces);

- speed humps at the junctions (the humps of various types installed within the junction zone, 15 pieces). Junction zone is a $200 \mathrm{~m}$ long distance on the major road and a $150 \mathrm{~m}$ long distance on the minor road from the crossing point of the axes of roads [12].

The speed humps, situated more than $600 \mathrm{~m}$ distance from each other (sections do not overlap) were analysed as individual objects, because the speed is not constant and the sufficient efficiency of implemented measures cannot be achieved in such distance. And vice versa, when the distance between speed humps is less than $600 \mathrm{~m}$ (sections overlap), the implemented measures were analysed as single objects. It is admitted that in this case efficiency of implemented measures is sufficient [13]:

- when a recurring obstacle is visible for the drivers they do not try to increase the speed;

- the driver „wakes up“, the factor of surprise works, therefore recurring speed hump is expected.

\section{Effect of vertical traffic calming measures on the change in the number of fatal and injury accidents}

For the analysis of fatal and injury accidents the data was collected of fatal and injury accidents having occurred 4 years before the installation of vertical traffic calming measure and in a time period after its installation until 31 December 2011 within the zone of measure operation. Since the time periods before and after installation of safety measure differ, in order to properly assess the effect of vertical traffic calming measures on traffic safety the fatal and injury accidents were analysed in time periods of the same length before and after measure installation.

On the sections, where the speed humps of trapeze shape were placed, the number of fatal and injury accidents decreased by $36 \%$, the number of people killed - by $100 \%$, the number of people injured - by about $45 \%$. The obtained results show that the largest influence on the decrease of collisions was made by implementation of trapeze shape speed humps (Table 1).

On the sections where the raised pedestrian crossings were installed the number of fatal and injury accidents decreased by about $65 \%$, the number of people killed - by about $83 \%$, and the number of people injured - by about $68 \%$. The obtained results show that the largest influence on the decrease of fatal and injury accidents when pedestrians or bicycles come into collision was made by implementation of raised pedestrian crossings (Table 2).

On the road sections where the speed bumps were installed the number of fatal and injury accidents decreased by about $73 \%$, the number of people injured - by about $77 \%$. The obtained results show that the largest influence on the decrease of fatal and injury accidents when pedestrians or bicycles have an accident or come into collision was made by implementation of speed bumps (Table 3).

When studying accidents at the junctions it was determined that they are influenced not only by speed humps but also by another complex traffic calming measures, i. e. separating safety islands, information shields, etc. Investigation showed that almost at all junctions the speed humps are installed only on the minor roads. Installation of speed humps on the minor roads results decreased number of entrances to the main roads when the traffic situation in main road is not sufficiently assessed. The driver, when reducing speed or coming to a full stop before the major road, has a possibility to assess the speed of upcoming vehicles on the major road and distance to them. At the junctions where vertical traffic calming measures were installed the number of fatal and injury accidents decreased by about $44 \%$, the number of people killed - by $75 \%$, and the number of people injured - by about $29 \%$. Distribution of fatal and injury accidents before and after the speed humps were implemented at the junctions is given in Table 4. 


\section{L. Čygaite et al. / The $9^{\text {th }}$ Conference Environmental Engineering. Selected Papers, Article number: enviro.2014.150}

Table 1. Distribution of fatal and injury accidents on sections where trapeze shape speed humps were implemented

\begin{tabular}{|c|c|c|c|c|c|c|}
\hline \multirow{2}{*}{ Accident type } & \multicolumn{2}{|c|}{ Accidents } & \multicolumn{2}{|c|}{ Killed } & \multicolumn{2}{|c|}{ Injured } \\
\hline & before installation & after installation & before installation & after installation & before installation & after installation \\
\hline Collision & $83 \%$ & $17 \%$ & $100 \%$ & $0 \%$ & $78 \%$ & $22 \%$ \\
\hline $\begin{array}{l}\text { Collision with } \\
\text { pedestrian }\end{array}$ & $60 \%$ & $40 \%$ & $0 \%$ & $0 \%$ & $60 \%$ & $40 \%$ \\
\hline Collision with bicycle & $0 \%$ & $100 \%$ & $0 \%$ & $0 \%$ & $0 \%$ & $100 \%$ \\
\hline $\begin{array}{l}\text { Collision with } \\
\text { obstacle }\end{array}$ & $75 \%$ & $25 \%$ & $0 \%$ & $0 \%$ & $90 \%$ & $10 \%$ \\
\hline Overturning & $0 \%$ & $0 \%$ & $0 \%$ & $0 \%$ & $0 \%$ & $0 \%$ \\
\hline Other accidents & $0 \%$ & $100 \%$ & $0 \%$ & $0 \%$ & $0 \%$ & $100 \%$ \\
\hline Total & $61 \%$ & $39 \%$ & $100 \%$ & $0 \%$ & $69 \%$ & $31 \%$ \\
\hline
\end{tabular}

Table 2. Distribution of fatal and injury accidents on the sections where raised pedestrian crossings were implemented

\begin{tabular}{|c|c|c|c|c|c|c|}
\hline \multirow{2}{*}{ Accident type } & \multicolumn{2}{|c|}{ Accidents } & \multicolumn{2}{|c|}{ Killed } & \multicolumn{2}{|c|}{ Injured } \\
\hline & before installation & after installation & before installation & after installation & before installation & after installation \\
\hline Collision & $62 \%$ & $38 \%$ & $100 \%$ & $0 \%$ & $71 \%$ & $29 \%$ \\
\hline $\begin{array}{l}\text { Collision with } \\
\text { pedestrian }\end{array}$ & $82 \%$ & $18 \%$ & $100 \%$ & $0 \%$ & $81 \%$ & $19 \%$ \\
\hline Collision with bicycle & $85 \%$ & $15 \%$ & $50 \%$ & $0 \%$ & $91 \%$ & $9 \%$ \\
\hline $\begin{array}{l}\text { Collision with } \\
\text { obstacle }\end{array}$ & $63 \%$ & $37 \%$ & $0 \%$ & $0 \%$ & $67 \%$ & $33 \%$ \\
\hline Overturning & $100 \%$ & $0 \%$ & $0 \%$ & $0 \%$ & $100 \%$ & $0 \%$ \\
\hline Other accidents & $0 \%$ & $100 \%$ & $0 \%$ & $0 \%$ & $0 \%$ & $100 \%$ \\
\hline Total & $75 \%$ & $25 \%$ & $86 \%$ & $14 \%$ & $76 \%$ & $24 \%$ \\
\hline
\end{tabular}

Table 3. Distribution of fatal and injury accidents on the sections where speed bumps were implemented

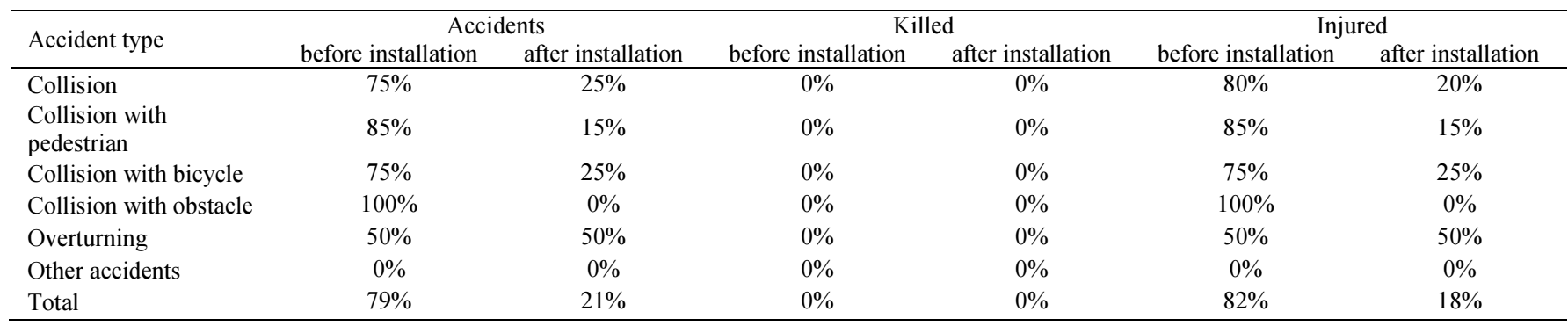

Table 4. Distribution of fatal and injury accidents at the junctions where speed humps were implemented

\begin{tabular}{|c|c|c|c|c|c|c|}
\hline \multirow{2}{*}{ Accident type } & \multicolumn{2}{|c|}{ Accidents } & \multicolumn{2}{|c|}{ Killed } & \multicolumn{2}{|c|}{ Injured } \\
\hline & before installation & after installation & before installation & after installation & before installation & after installation \\
\hline Collision & $59 \%$ & $41 \%$ & $50 \%$ & $50 \%$ & $56 \%$ & $44 \%$ \\
\hline $\begin{array}{l}\text { Collision with } \\
\text { pedestrian }\end{array}$ & $50 \%$ & $50 \%$ & $100 \%$ & $0 \%$ & $0 \%$ & $100 \%$ \\
\hline Collision with bicycle & $67 \%$ & $33 \%$ & $100 \%$ & $0 \%$ & $0 \%$ & $100 \%$ \\
\hline Collision with obstacle & $100 \%$ & $0 \%$ & $0 \%$ & $0 \%$ & $100 \%$ & $0 \%$ \\
\hline Overturning & $67 \%$ & $33 \%$ & $0 \%$ & $0 \%$ & $75 \%$ & $25 \%$ \\
\hline Total & $64 \%$ & $36 \%$ & $80 \%$ & $20 \%$ & $58 \%$ & $42 \%$ \\
\hline
\end{tabular}

Investigation of traffic accidents in settlements has showed that the layout of speed humps throughout the length of settlements helps to keep uniform speed. Drivers after passing the obstacle (hump) expect its recurrence and do not increase the driving speed. It should be noted that in the analysis of fatal and injury accidents on the section of settlements some sections duplicate with the previously analysed sections of the roads, separately for each type of traffic calming measures. When investigating sections by the settlements where humps were implemented it was found out that after their implementation fatal and injury accidents decreased on the average - by $49 \%$, the number of people killed - by $75 \%$, and the number of people injured - by $50 \%$. Distribution of fatal and injury accidents before and after vertical traffic calming measures were implemented in settlements is given in Table 5.

The change in the number of fatal and injury accidents after installation of vertical traffic calming measures is shown in Fig. 1. 
Table 5. Distribution of fatal and injury accidents on the sections where vertical traffic calming measures were implemented in settlements

\begin{tabular}{lccccc}
\hline \multirow{2}{*}{ Accident type } & \multicolumn{2}{c}{ Accidents } & \multicolumn{2}{c}{ Killed } & \multicolumn{2}{c}{ Injured } \\
& before installation & after installation & before installation & after installation & before installation \\
after installation
\end{tabular}

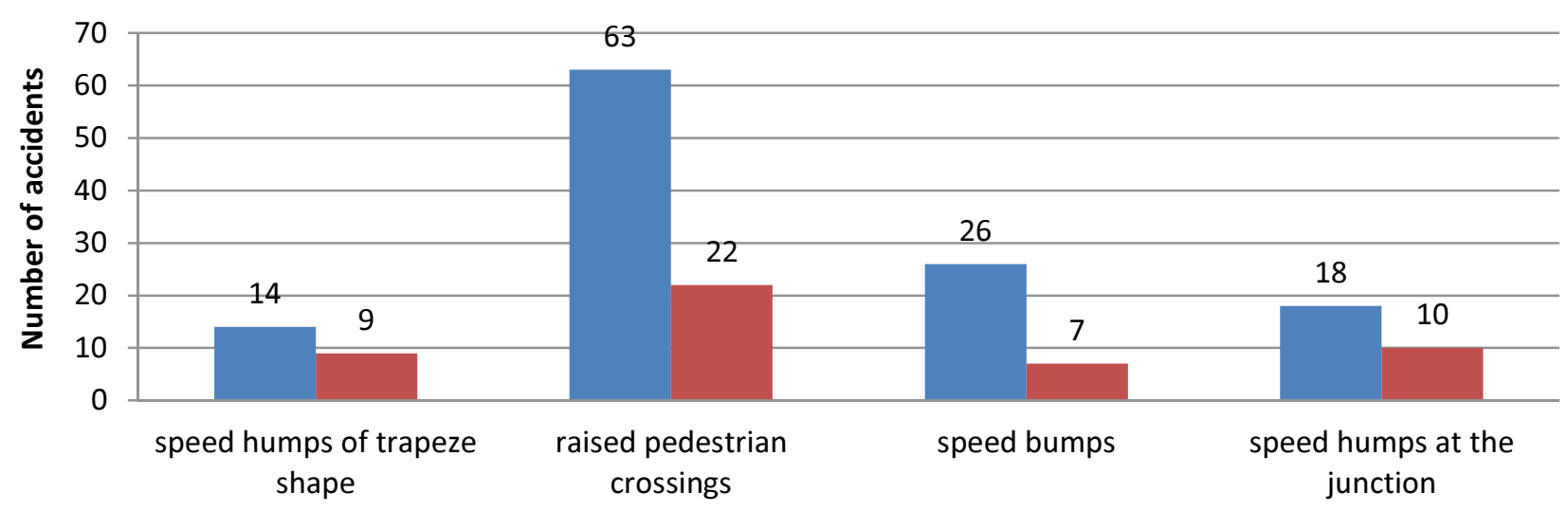

Data before installation of vertical traffic calming measures

Data after installation of vertical traffic calming measures

Fig. 1. Change in the number of fatal and injury accidents after installation of vertical traffic calming measures field

\section{Traffic-generated noise investigations at the sites of vertical traffic control measures}

Before noise level measurements 22 sites were selected from the list of previously analysed vertical traffic calming measures according to fatal and injury accidents. They were divided into two groups:

- Speed humps of trapeze shape or raised pedestrian crossings of trapeze shape (3 $\mathrm{m}$ long and $10 \mathrm{~cm}$ high on the average).

This group includes 1 asphalt speed hump of trapeze shape and 14 asphalt or prefabricated raised pedestrian crossings (Table 6).

- Speed bumps ( $0.5 \mathrm{~m}$ long and $5 \mathrm{~cm}$ high on the average). This group includes 7 circular speed bumps from prefabricated plastic segments (Table 6).

The following investigations were carried out in the sites of vertical traffic calming measures and adjacent road sections:

- Noise level measurements;

- Traffic flow measurements.

\subsection{Noise level measuring methodology}

In the selected sites of vertical traffic calming measures, noise levels are determined in three measuring sites where measurements are taken simultaneously using three noise meters and the passing traffic flow being the same. Two measuring sites are selected close to a vertical traffic calming measure - in sites where the largest noise emission is formed $(\mathrm{A}, \mathrm{B})$, and the third - check measuring site is selected at a larger distance from a calming measure where noise emission has no effect on the vehicles passing through vertical traffic calming measure (C). In case of uninterrupted traffic flow measurements are taken for $30 \mathrm{~min}$, in case of interrupted traffic flow, i.e., less than 1 vehicle in 1 min, noise level is measured for each vehicle individually.

Noise levels are assessed by comparing measurement results, obtained at vertical traffic calming measure, with noise level values measured at the check point where noise level is not affected by vertical traffic calming measure. A principle scheme of noise measuring sites is given in Fig. 2. The generated noise is measured at a $1.5 \mathrm{~m}$ distance to the edge of road, a microphone is raised to $1.5 \mathrm{~m}$ height from the ground surface at a distance of at least $0.5 \mathrm{~m}$ from the specialist who take measurements in a way of targeting microphone to the side of noise source. 
Table 6. The list of vertical traffic calming measures selected for the measurements

\begin{tabular}{|c|c|c|c|c|}
\hline $\begin{array}{l}\text { Road } \\
\text { number }\end{array}$ & Location & Settlement & $\begin{array}{l}\text { State road maintenance } \\
\text { enterprise (RK) }\end{array}$ & $\begin{array}{l}\text { Type of vertical traffic } \\
\text { calming measure }\end{array}$ \\
\hline 132 & $24,130 \mathrm{~km}$ & Seirijai & Alytaus RK & Trapeze shape \\
\hline 138 & $0,109 \mathrm{~km}$ & Vilkaviškis I & Marijampolès RK & Raised pedestrian crossings \\
\hline 138 & $0,381 \mathrm{~km}$ & Vilkaviškis II & Marijampolès RK & Raised pedestrian crossings \\
\hline 171 & $0,662 \mathrm{~km}$ & Avižieniai & Vilniaus RK & Raised pedestrian crossings \\
\hline 182 & $4,380 \mathrm{~km}$ & Netičkampis & Marijampolès RK & Raised pedestrian crossings \\
\hline 186 & $0,375 \mathrm{~km}$ & Kybartai I & Marijampolès RK & Raised pedestrian crossings \\
\hline 5214 & $2,910 \mathrm{~km}$ & Klevinè & Vilniaus RK & Raised pedestrian crossings \\
\hline 102 & $84,700 \mathrm{~km}$ & Švenčionys & Vilniaus RK & Raised pedestrian crossings \\
\hline 116 & $1,500 \mathrm{~km}$ & Širvintos & Vilniaus RK & Raised pedestrian crossings \\
\hline 122 & $105,260 \mathrm{~km}$ & Vaivadai & Panevėžio RK & Raised pedestrian crossings \\
\hline 131 & $26,550 \mathrm{~km}$ & Simnas & Alytaus RK & Raised pedestrian crossings \\
\hline 172 & $52,657 \mathrm{~km}$ & Molètai & Utenos RK & Raised pedestrian crossings \\
\hline 185 & $0,571 \mathrm{~km}$ & Vilkaviškis III & Marijampolès RK & Raised pedestrian crossings \\
\hline 202 & $10,830 \mathrm{~km}$ & Pagiriai & Vilniaus RK & Raised pedestrian crossings \\
\hline 220 & $49,627 \mathrm{~km}$ & Pivašiūnai & Alytaus RK & Raised pedestrian crossings \\
\hline A7 & $\begin{array}{l}40,063 \mathrm{~km} \\
40,097 \mathrm{~km}\end{array}$ & Kybartai II & Marijampolès RK & Circular shape \\
\hline 120 & $53,511 \mathrm{~km}$ & Svėdasai & Utenos RK & Circular shape \\
\hline 121 & $\begin{array}{l}16,336 \mathrm{~km} \\
16,369 \mathrm{~km}\end{array}$ & Troškūnai & Utenos RK & Circular shape \\
\hline 138 & $\begin{array}{l}11,251 \mathrm{~km} \\
11,282 \mathrm{~km}\end{array}$ & Žalioji & Marijampolès RK & Circular shape \\
\hline 147 & $\begin{array}{l}1,440 \mathrm{~km} \\
1,490 \mathrm{~km}\end{array}$ & Tauragè II & Tauragès RK & Circular shape \\
\hline 164 & $\begin{array}{l}141,020 \mathrm{~km} \\
141,070 \mathrm{~km}\end{array}$ & Tauragė I & Tauragės RK & Circular shape \\
\hline 5106 & $0,212 \mathrm{~km}$ & Vilkaviškis IV & Marijampolès RK & Circular shape \\
\hline
\end{tabular}

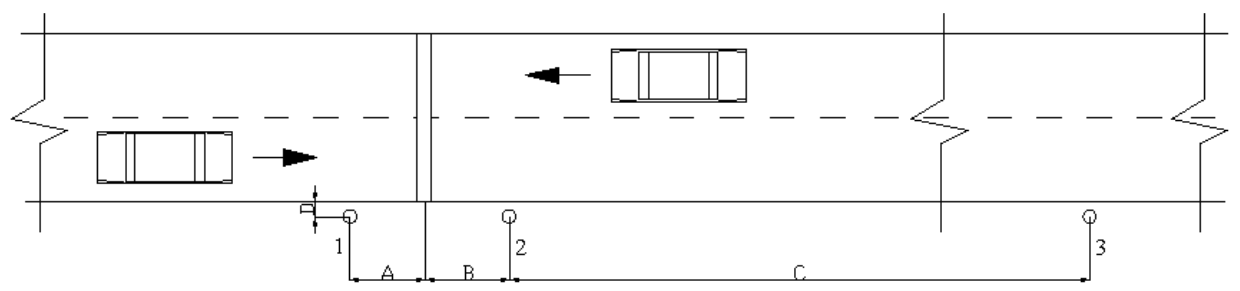

Fig. 2. A principle scheme of noise measuring sites

To measure noise from mobile sources a precision hand-held sound lever meter Bruel\&Kjaer 2260 is used. Using the onsite measurement instrument Bruel\&Kjaer 2260 the values are determined with an error of $1.5 \%$. Before taking noise level measurements meteorological weather conditions are determined: relative humidity, air temperature and wind speed.

\subsection{Traffic flow measuring methodology}

The aim of measuring traffic flow is to determine the flow of passing vehicles and its effect on noise level. Traffic flow is measured in all traffic directions. It is measured simultaneously with noise level. Measurement of traffic flow helps to calculate how many and of what type vehicles pass in one or another direction in the given road location at the given time interval.

\subsection{Analysis and evaluation of traffic flow measurement}

Having measured the values of equivalent noise in all measuring sites at raised pedestrian crossings and at a speed hump of trapeze shape, a conclusion could be made (Fig. 4) that raised asphalt crossings have no effect on the increase in noise level since the approaching vehicles reduce speed and when passing through the crossing do not cause increase in noise emission.

Once the vehicles passed through a raised asphalt crossing, noise level increases since the vehicles pick up speed causing more engine revs and higher noise emission. At raised crossings the equivalent noise level in the second measuring sites is in all cases higher than that when vehicles pass through the crossing itself. The highest noise levels were recorded in check sites where vehicles travel at a usual speed allowed in settlement, without any obstructions. This is conditioned by the fact that the higher driving speed the higher noise level.

Fig. 5 gives the measured equivalent noise level values in all measuring sits at circular speed bumps. Based on measurement data, it can be concluded that circular speed bumps have no effect on the increase in noise level since the 
coming vehicles reduce speed, and the measured equivalent noise level is in all cases higher in the check measuring site compared to the first and the second measuring sites at the bump.

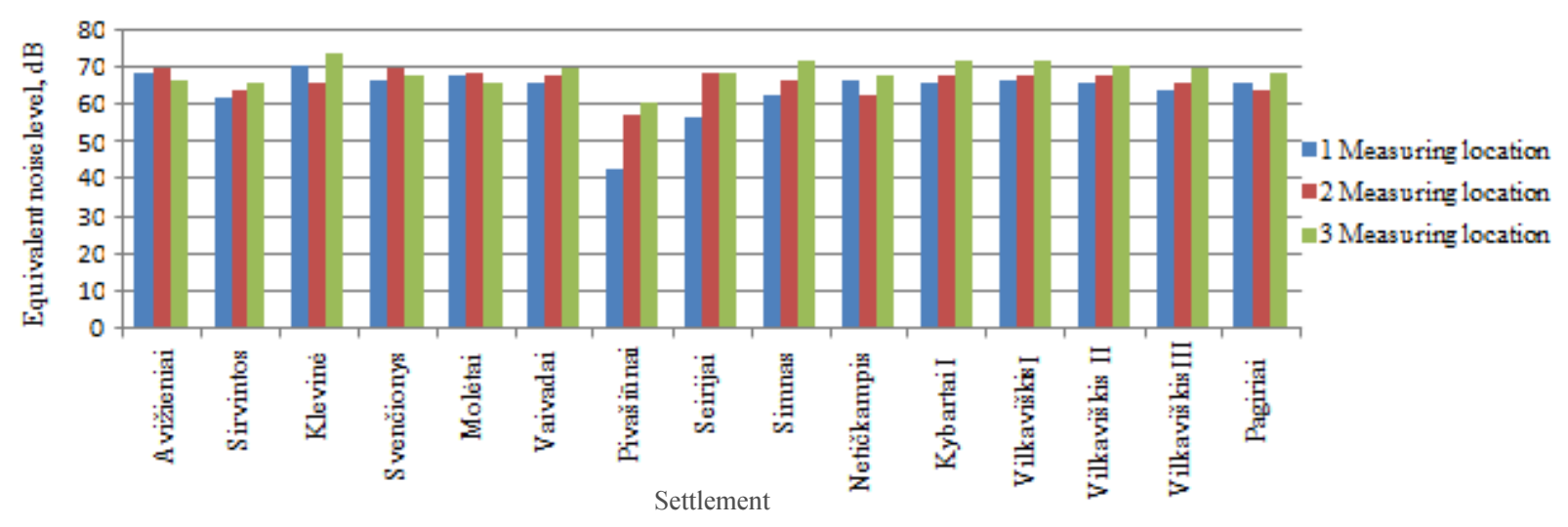

Fig. 4. The equivalent noise level measured at raised pedestrian crossings and at a speed hump of trapeze shape

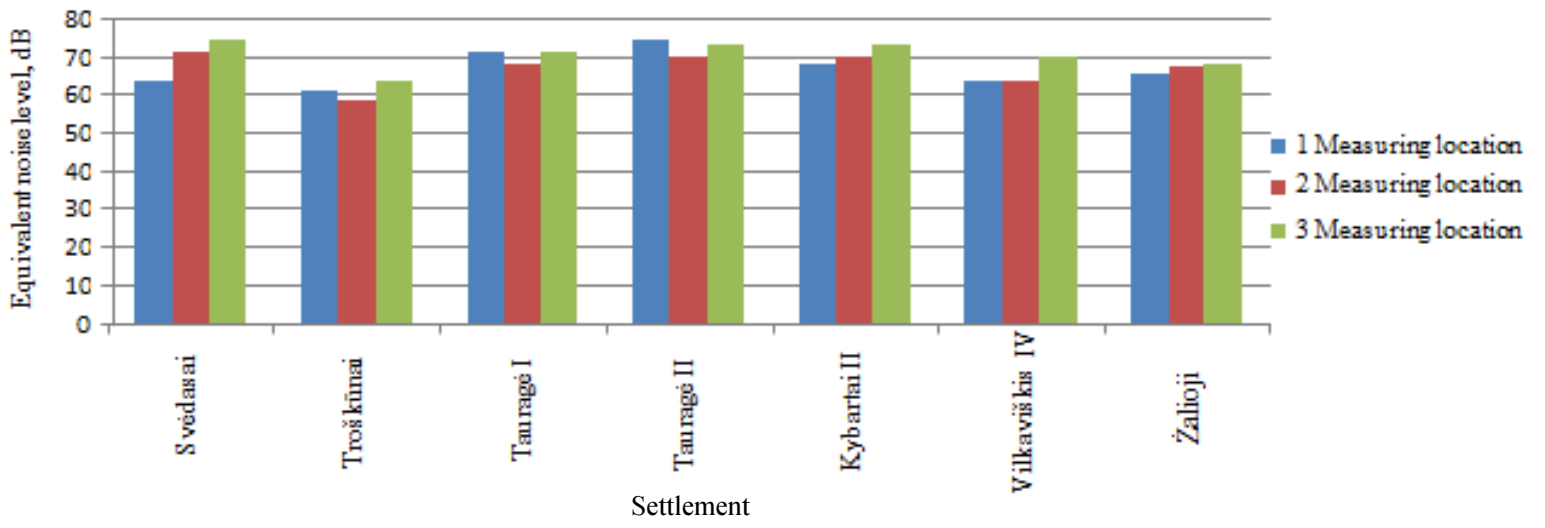

Fig. 5. The equivalent noise level measured at speed bumps

Once the vehicles passed through a circular speed bump, as distinct from raised crossings, in many cases noise level at the bump was higher than in the second measuring site where the vehicles pick up speed causing more engine revs and higher noise emission. The highest noise levels were measured in check measuring sites where vehicles travel at a usual speed allowed in settlement, without any obstructions. This is conditioned by the fact that the higher driving speed the higher noise level.

The increase in equivalent noise level at vertical traffic calming measure compared to the check site from 22 selected measuring sites was recorded only in 4: Avižieniai, Švenčionys, Molètai and Tauragè (II).

\section{Conclusions}

Research on the impact of vertical traffic calming measures on the environment has determined that the studied measures in sites of their installation do not increase the traffic-generated equivalent noise level. Results of the measurements of equivalent noise level showed that at speed humps of trapeze shape and raised pedestrian crossings in the first measuring site almost in all cases noise level was from 1 to $18 \mathrm{~dB}$ lower than in the check measuring site. In the second measuring site where the vehicles pick up speed almost in all cases noise level was by 2 to $8 \mathrm{~dB}$ lower than in the check measuring site. Results of the measurements of equivalent noise level showed that at speed bumps in the first measuring site almost in all cases noise level was from 2 to $11 \mathrm{~dB}$ lower than in the check measuring site. In the second measuring site where the vehicles pick up speed almost in all cases noise level was by 1 to $7 \mathrm{~dB}$ lower than in the check measuring site.

It was determined that before the installation of vertical traffic calming measures 121 accidents took place where 147 people were injured and 11 people were killed. After their installation 48 road accidents were recorded where 55 were injured and 2 were killed. After installation of vertical traffic calming measures the number of fatal and injury accidents decreased by $60 \%$, the number of people injured - by $63 \%$, the number of people killed - by $82 \%$. 


\section{References}

[1] Lietuvos automobiliu keliu direkcija prie Susisiekimo ministerijos [Lithuanian Road Administration under the Ministry of Transport and Communications]. 2013. Iskaitiniu eismo ivvkiu statistika Lietuvoje 2009-2012 m. [Statistics of Fatal and Injury Road Accidents in Lithuania, 20092012]. Vilnius. 109 p.

[2] Baubinas, A.; Vainauskas, S. 1998. Gyvenamosios aplinkos įtaka moksleivių sveikatai [Influence of Living Environment on Schoolchildren’s Health], Aplinkos inžinerija [Environmental Engineering] 6(1): 4-8.

[3] Sandberg, U.; Ejsmont, A. J. 2002. Tyre/Road Noise Reference Book. INFORMEX, Harg, SE-59040 Kisa, Sweden. 616 p. aISBN 91-631-2610-9.

[4] Freitas, E.; Mendonça, C.; Santos, J.A.; Murteira, C.; Ferreira, J.P. 2012. Traffic noise abatement: How different pavements, vehicle speeds and traffic densities affect annoyance levels, Transportation Research Pard D: Transport and Environment 17(4): 321-326.

[5] Leipus, L.; Butkus, D.; Januševičius T. 2010. Research on motor transport produced noise on gravel and asphalt roads, The Baltic Journal of Road and Bridge Engineering 5(3): 125-131. http://dx.doi.org/10.3846/bjrbe.2010.18

[6] Cottrell, W. D.; Kim, N.; Martin, P. T.; Perrin Jr., J. 2006. Effectiveness of traffic management in Salt Lake City, Utah, Journal of Safety Research 37(1): 27-41. http://dx.doi.org/10.1016/j.jsr.2005.08.007

[7] Kokowski, P.; Makarewicz, R. 2006. Predicted effects of a speed bump on light vehicle noise, Applied Acoustics 67(6): 570-579. http://dx.doi.org/10.1016/j.apacoust.2005.10.001

[8] Behzad, M.; Hodaei, M.; Alimohammadi, I. 2007. Experimental and numerical investigation of the effect of a speed bump on car noise emission level, Applied Acoustics 68(11-12): 1346-1356. http://dx.doi.org/10.1016/j.apacoust.2006.07.003

[9] Elvik, R.; Hoye, A.; Vaa, T.; Sorensen, M. 2009. The Handbook of Road Safety Measures Second Edition. Emerald Group Publishing Limited, Howard House, Wagon Lane, Bingley BD 16 1WA, UK. 1124 p. ISBN: 978-1-84855-250-0.

[10] Chen, L.; Chen, C.; Ewing, R.; McKnight, C. E.; Srinivasan, R.; Roe, M. 2013. Safety countermeasures and crash reduction in New York CityExperience and lessons learned, Accident Analysis \& Prevention 50: 312-322.

[11] Daniel, B. D.; Nicholson, A.; Koorey, G. 2012. The effects of vertical speed control devices on vehicle speed and noise emission, in 25th ARRB Conference - Shaping the future: Linking policy, research and outcomes, Perth, Australia, 2012.

[12] Lietuvos Respublikos Susisiekimo ministerija [The Ministry of Transport and Communications of the Republic of Lithuania]. 2011. Avaringumo ruožu nustatymo valstybinés reikšmés keliuose metodika [Methodology for Identification of Accident Concentration Places on National Significance roads]. Vilnius.

[13] Lietuvos automobiliu keliu direkcija prie Susisiekimo ministerijos [Lithuanian Road Administration under the Ministry of Transport and Communications]. 2010. Inžineriniu saugaus eismo priemoniu projektavimo ir naudojimo rekomendacijos $R$ ISEP 10 [Recommendations on the Design and Use of Engineering Safety Measures]. Vilnius, 123 p. 